\title{
Research Letter \\ Increased Chlorophyll Levels in the Southern Caspian Sea Following an Invasion of Jellyfish
}

\author{
Ahmet E. Kideys, ${ }^{1}$ Abolghaseem Roohi, ${ }^{2}$ Elif Eker-Develi, ${ }^{3}$ Frédéric Mélin, ${ }^{3}$ and Doug Beare ${ }^{4}$ \\ ${ }^{1}$ Dolmabahce Sarayi, 2 Hareket Kosku, 34353 Besiktas, Istanbul, Turkey \\ ${ }^{2}$ Mazandaran Fisheries Research Center, Caspian Sea Research Institute in Ecology, P.O. Box 961, Sari, Iran \\ ${ }^{3}$ European Commission-Joint Research Centre, Institute for Environment and Sustainability, TP272, 21027 Ispra, Italy \\ ${ }^{4}$ European Commission - Joint Research Centre, Institute for the Protection and Security of the Citizen, TP051, 21027 Ispra, Italy
}

Correspondence should be addressed to Elif Eker-Develi, elif.eker-develi@jrc.it

Received 10 December 2007; Accepted 18 February 2008

Recommended by Mark Gibbons

A significant correlation was observed between satellite derived chlorophyll $a$ ( $\mathrm{Chl} a$ ) concentrations and the biomass of the invasive comb jellyfish Mnemiopsis leidyi in the southern Caspian Sea. By consuming the herbivorous zooplankton, the predatory ctenophore M. leidyi may have caused levels of Chl $a$ to rise to very high values $\left(\sim 9 \mathrm{mg} \mathrm{m}^{-3}\right)$ in the southern Caspian Sea. There might also be several other factors concurrent with predation effects of M. leidyi influencing Chl $a$ levels in this region, such as eutrophication and climatic changes which play major roles in nutrient, phytoplankton, and zooplankton variations. The decrease in pelagic fishes due to overfishing, natural, and anthropogenic impacts might have provided a suitable environment for M. leidyi to spread throughout this enclosed basin.

Copyright (C) 2008 Ahmet E. Kideys et al. This is an open access article distributed under the Creative Commons Attribution License, which permits unrestricted use, distribution, and reproduction in any medium, provided the original work is properly cited.

The Caspian Sea is the largest inland water body in the world sustaining large stocks of small commercially important zooplanktivorous, pelagic fish. In such ecosystems, a consistent, significant decrease in numbers of grazing zooplankton would be expected to result in a decrease in pelagic fish stocks and their predators.

Mnemiopsis leidyi is a highly fecund comb jelly feeding extensively on zooplankton. The main diet of this ctenophore in the southwestern Caspian Sea was found to be copepods ( 45\%) during May 2000-March 2001 [1], as found previously in the Black Sea [2]. Predation impacts of M. leidyi on zooplanktic prey organisms have been previously demonstrated in its native waters, the western Atlantic [3], and in introduced regions $[4,5]$. Furthermore, a recent study based on feeding experiments in the Caspian Sea suggested that the predation pressure of $M$. leidyi alone would be sufficient to suppress available stocks of zooplankton within a short period (1 day in summer and 3-8 days during winter/spring) [6] and thus would allow phytoplankton biomass to increase.

In the late 1990s, M. leidyi was transported into the Caspian Sea [5], possibly in ballast water [5] and spread throughout the Caspian Sea within a few years $[1,5,7,10]$. Overfishing, eutrophication, and climatic changes (such as global warming) have been suggested as triggering factors of the blooms of jellyfish in both native and introduced waters [11-14]. Native predators (e.g., goby species [15]) of M. lei$d y i$ in the Caspian Sea did not appear to be as efficient as $B$. ovata, which feeds almost exclusively on M. leidyi [16], in the Black Sea, in consuming M. leidyi biomass [17].

At the end of the 1991-2000 period, in which relatively good recruitment and high spawning-stock biomass of anchovy kilka were recorded, fishing mortality $\left(1.8 \mathrm{y}^{-1}\right)$ peaked in 1999 [15], which might have made kilka fish stocks vulnerable to external stress. Following the period of intensive overfishing and peak levels of M. leidyi ( $900 \mathrm{~g} \mathrm{~m}^{-2}$ in 2001), a sharp decrease in fish catch data was observed [5]. M. lei$d y i$ has already been suggested as the primary reason for the dramatic recruitment failure of anchovy kilka from 2001 to 2004 in the Caspian Sea [15]. Other possible factors in the decline in kilka stocks could be related to natural (release of toxic gases by the activation of seismic plates [15], oil seeps from mud volcanoes [18]) and anthropogenic sources (e.g., oil leakage from petroleum industry [19]). 


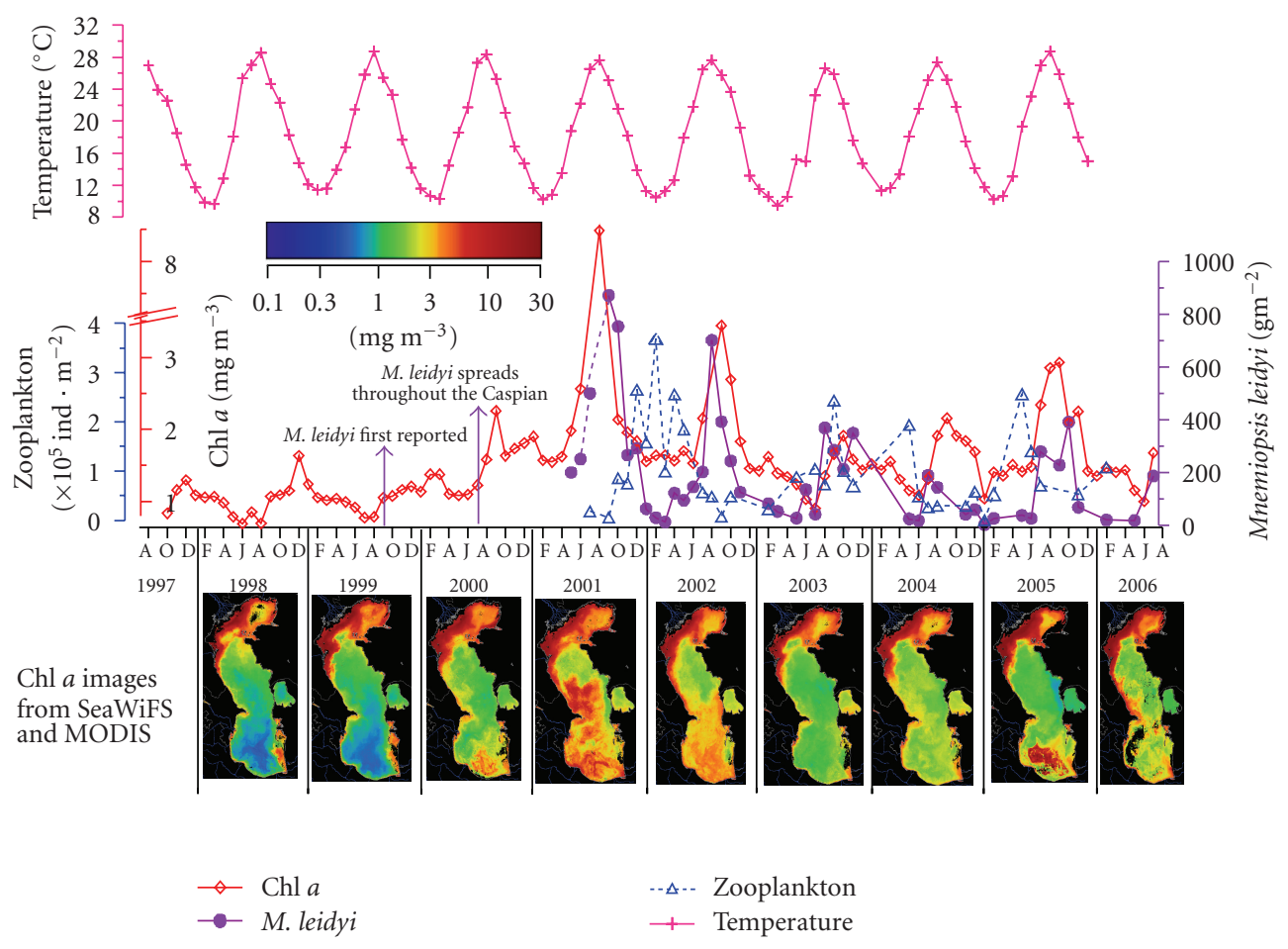

FIGURE 1: Spatiotemporal distribution of Chl $a$ concentration $\left(\mathrm{mg} \mathrm{m}^{-3}\right.$, note the broken scale here), zooplankton abundance (ind $\left.\cdot \mathrm{m}^{-2}\right)$, Mnemiopsis leidyi biomass ( $\mathrm{g} \mathrm{m}^{-2}$ values for June and August 2001 are from Shiganova et al. [7]), and sea surface temperature $\left({ }^{\circ} \mathrm{C}\right)$ obtained from NOAA in the Caspian Sea. Note the strong difference in Chl $a$ distributions (as seen from satellite during a warm period, September) before (1998 and 1999) and after Mnemiopsis leidyi impact (2001 and 2006) in the lower section of the figure.

TABLE 1: Zooplankton $(>100 \mu \mathrm{m})$ and phytoplankton quantities before and after Mnemiopsis leidyi invasion in the southern Caspian Sea ( \pm standard deviation).

\begin{tabular}{|c|c|c|c|c|}
\hline & Before M. leidyi & Period (reference) & After M. leidyi* & Period \\
\hline \multirow{4}{*}{ Zooplankton Abundance $\left(\times 10^{5}\right.$ ind $\left.\cdot \mathrm{m}^{-2}\right)$} & $5.1 \pm 3.7$ & 1994 summer [8] & $0.19 \pm 0.19$ & 2001 summer \\
\hline & $2.8 \pm 1.3$ & 1995 autumn [8] & $0.55 \pm 0.42$ & 2001 autumn \\
\hline & $3.1 \pm 2.2$ & 1996 summer [8] & $0.52 \pm 0.26$ & 2002 summer \\
\hline & $4.6 \pm 1.9$ & 1996 autumn [8] & $0.28 \pm 0.10$ & 2002 autumn \\
\hline \multirow{3}{*}{ Phytoplankton abundance $\left(\times\right.$ million cells $\left.\mathrm{m}^{-3}\right)$} & 14.9 & 1962 summer [9] & $108 \pm 99$ & summer-autumn 2001 \\
\hline & 17.2 & 1975 summer [9] & - & - \\
\hline & 8.8 & 1976 summer [9] & $34 \pm 71$ & summer-autumn 2002 \\
\hline
\end{tabular}

${ }^{*}$ Present study (see methods in Supplementary Material). [8]: from Mazandaran region, the zooplankton sampling and analyses methods were the same as in the present study; [9]: from Southern Caspian Sea.

Despite the substantial decreases in zooplanktivorous fish and still available phytoplankton biomass (inferred from Chl $a$ levels), sharp declines in the zooplankton abundance, particularly in late summer-early autumn, could be related to predation by $M$. leidyi in our study (see Figure 1). When the surface waters cooled in winter, $M$. leidyi biomass decreased substantially and a limited recovery of zooplankton abundance was observed. The average zooplankton abundance in the summers and autumns of 2001 and 2002 was one order of magnitude lower compared to the period before M. leidyi invasion (see Table 1).

Before the M. leidyi invasion, the minimum and maximum monthly composite Chl a levels in the southern
Caspian were in October 1997 and in December 1998, respectively, (see Figure 1) but when M. leidyi spread into the Caspian, Chl $a$ levels gradually increased and reached extremely high levels in August 2001 contemporaneous with the highest recorded M. leidyi biomass and the lowest zooplankton abundance (see Figure 1). According to statistical analyses, in addition to there being a significant, positive linear relationship between levels of M. leidyi and Chl $a$ (Pearson test, $r=+0.6, t=4.5, d f=40, P=.000005$ ), there was also a significant change in the seasonal cycle of $\mathrm{Chl} a$ concentration, that is, the peak occurred in winter-spring before $M$. leidyi invaded and in late summer afterwards (see Figure 1 and also see supplementary material available at 
doi://10.1155/2007/85642 for methods and statistical analyses). Phytoplankton cell abundance was also much higher between 2001 and 2002, compared to years when M. leidyi was absent (see Table 1). Chl $a$ concentrations during the cooler months fell when $M$. leidyi levels had also decreased.

Inorganic nutrient concentrations were reported to be low according to a few available publications in the southern Caspian Sea [20, 21]. However, it was also noted that Iranian lagoons and coastal regions have been steadily polluted with anthropogenic sources (fertilisers and pesticides used in agriculture and increased nutrient load of river flows due to deforestation of woodland) since the early 1980s [22-24]. Thus, simultaneous rises in nutrient concentrations and $M$. leidyi biomass might also have contributed to increases in Chl $a$ values.

Unfortunately, it is difficult to assess the impacts of eutrophication and climate on phytoplankton and zooplankton abundance in the Caspian Sea due to a limitation in data availability. In the Black Sea, Oguz [25] suggested that severity of winters in 1992 and 1993 could cause an abrupt decrease of mesozooplankton and $M$. leidyi when fish stocks were at the lowest level and phytoplankton biomass was very high. Bilio and Niermann [13] also emphasized the possible effects of hydrological and meteorological regimes in the northern hemisphere on phyto and mesozooplankton changes. However, the relatively warm and stable temperature regime in the region [25] (see also Figure 1) is unlikely to explain Chl $a$ variations observed herein.

The reduction in herbivory due to extremely low levels of zooplankton is a possible factor determining enormous levels of Chl $a$ observed in the SeaWiFS data. High turnover of nitrogen and phosphorus by M. leidyi excretion [26] would also contribute to this consistently high phytoplankton growth. If the relation between M. leidyi and phytoplankton (Chl $a$ ) is compared in two different seas, the Caspian and Black Seas; it is observed that M. leidyi reached $\sim 2$ times higher maximum biomass $\left(2000 \mathrm{~g} \mathrm{~m}^{-2}\right.$ in 1990) in the Black Sea [5] than in the Caspian Sea, while Chl $a$ concentrations were $\sim 10$ times lower in the former sea (basin-scale Chl $a \sim 1 \mathrm{mg} \mathrm{m}^{-3}$ [27]) than the latter. Small size composition of $M$. leidyi and the dominance of juvenile ctenophores $[6,28]$ might have played a role in faster removal of zooplankton $[3,6]$ from the Caspian Sea leading to high phytoplankton biomass. In addition, distinct hydrological, physical, chemical (e.g., nutrients originating from anthropogenic and natural sources), and biological characteristics might have also led to differences in Chl $a$ concentrations in these two seas.

There have been a large number of very marked changes in planktonic systems around the World in recent decades [29]. While there is clearly a level of speculation in the approach of using correlation to infer the cause and impacts of such changes, correlation analysis has been widely used before and has certainly provided compelling evidence for gelatinous zooplankton having a variety of ecosystem effects $[30,31]$, some of which have been confirmed experimentally, for example, in mesocosm manipulations [32]. Certainly invasive species have caused profound ecological and economic problems in many ecosystems around the world. One of these species, M. leidyi, might have contributed to elevated Chl $a$ levels in the Caspian Sea, associated with the effects of eutrophication.

\section{ACKNOWLEDGMENT}

This study is a cooperating project of the Census of Marine Zooplankton (CMarZ), a field project of the Census of Marine Life.

\section{REFERENCES}

[1] A. G. Kasimov, "New introduced species in the Caspian SeaMnemiopsis leidyi," in Proceedings of the 1st International Workshop on The Invasion of the Caspian Sea by the Comb Jelly Mnemiopsis - Problems, Perspectives, Need for Action, A. Agassiz, Ed., p. 5, Baku, Azerbaijan, April 2001.

[2] E. Mutlu, "Distribution and abundance of ctenophores and their zooplankton food in the Black Sea. II. Mnemiopsis leidyi," Marine Biology, vol. 135, no. 4, pp. 603-613, 1999.

[3] E. E. Deason and T. J. Smayda, "Ctenophore-zooplanktonphytoplankton interactions in the Narragansett Bay, Rhode Island, USA, during 1972-1977," Journal of Plankton Research, vol. 4, no. 2, pp. 203-217, 1982.

[4] A. E. Kideys, "Ecology: fall and rise of the Black Sea ecosystem," Science, vol. 297, no. 5586, pp. 1482-1484, 2002.

[5] A. E. Kideys, A. Roohi, S. Bagheri, G. Finenko, and L. Kamburska, "Impacts of invasive ctenophores on the fisheries of the Black Sea and Caspian Sea," Oceanography, vol. 18, no. 2, pp. 76-85, 2005.

[6] G. A. Finenko, A. E. Kideys, B. E. Anninsky, et al., "Invasive ctenophore Mnemiopsis leidyi in the Caspian Sea: feeding, respiration, reproduction and predatory impact on the zooplankton community," Marine Ecology Progress Series, vol. 314, pp. 171-185, 2006.

[7] T. A. Shiganova, H. J. Dumont, A. F. Sokolsky, A. M. Kamakin, D. Tinenkova, and E. K. Kurasheva, "Population dynamics of Mnemiopsis leidyi in the Caspian Sea, and effects on the Caspian ecosystem," in Aquatic Invasions in the Black, Caspian, and Mediterranean Seas, H. Dumont, T. A. Shiganova, and U. Niermann, Eds., vol. 35, pp. 71-111, Kluwer Academic, Dordrecht, The Netherlands, 2004.

[8] M. Rowshantabari, "Distribution of zooplankton of the southern Caspian Sea (order copepoda)," M.S. thesis, Tarbiat Modares University, Tehran, Iran, 2001.

[9] A. N. Kosarev and E. A. Yablonskaya, The Caspian Sea, SPB Academic, Amsterdam, The Netherlands, 1994.

[10] A. E. Kideys and M. Moghim, "Distribution of the alien ctenophore Mnemiopsis leidyi in the Caspian Sea in august 2001," Marine Biology, vol. 142, no. 1, pp. 163-171, 2003.

[11] C. E. Mills, "Jellyfish blooms: are populations increasing globally in response to changing ocean conditions?" Hydrobiologia, vol. 451, no. 1-3, pp. 55-68, 2001.

[12] C. P. Lynam, M. J. Gibbons, B. E. Axelsen, et al., "Jellyfish overtake fish in a heavily fished ecosystem," Current Biology, vol. 16, no. 13, pp. R492-R493, 2006.

[13] M. Bilio and U. Niermann, "Is the comb jelly really to blame for it all? Mnemiopsis leidyi and the ecological concerns about the Caspian Sea," Marine Ecology Progress Series, vol. 269, pp. 173-183, 2004.

[14] J. E. Purcell, "Climate effects on formation of jellyfish and ctenophore blooms: a review," Journal of the Marine Biological 
Association of the United Kingdom, vol. 85, no. 3, pp. 461-476, 2005.

[15] G. M. Daskalov and E. V. Mamedov, "Integrated fisheries assessment and possible causes for the collapse of anchovy kilka in the Caspian Sea," ICES Journal of Marine Science, vol. 64, no. 3, pp. 503-511, 2007.

[16] R. Stone, "Attack of the killer jellies," Science, vol. 309, no. 5742, pp. 1805-1806, 2005.

[17] G. A. Finenko, Z. A. Romanova, G. I. Abolmasova, et al., "Ingestion, growth and reproduction rates of the alien Beroe ovata and its impact on the plankton community in Sevastopol Bay (the Black Sea)," Journal of Plankton Research, vol. 25, no. 5, pp. 539-549, 2003.

[18] L. Ireland, "The Caspian: hydrobiological survey of the chirag oilfield area," Azerbaijan International, 1994.

[19] M. G. Karpinsky, "Aspects of the Caspian Sea benthic ecosystem," Marine Pollution Bulletin, vol. 24, no. 8, pp. 384-389, 1992.

[20] H. J. Dumont, "The Caspian lake: history, biota, structure, and function," Limnology and Oceanography, vol. 43, no. 1, pp. 4452, 1998.

[21] V. V. Sapozhnikov, "Processes of the accumulation of nutrients in the deep-water basins of the central and southern areas of the Caspian Sea," Oceanology, vol. 42, no. 5, pp. 646-650, 2002.

[22] CEP, "National report of Iran for Caspian environment programme," Tech. Rep., Programme Coordination Unit, Baku, Azerbaijan, 1998.

[23] F. Stolberg, O. Borysova, I. Mitrofanov, V. Barannik, and P. Eghtesadi, "Global international waters assessment, Caspian Sea," Regional Assessment Report, University of Kalmar, Kalmar, Sweden, 2006.

[24] M. A. Salmanov, Ecology and Biological Productivity of the Caspian Sea, Institute of Zoology, Baku, Azerbaijan, 1999.

[25] T. Oguz, "Black Sea ecosystem response to climatic teleconnections," Oceanography, vol. 18, pp. 122-133, 2005.

[26] P. Kremer, "Respiration and excretion by the ctenophore Mnepiopsis leidyi," Marine Biology, vol. 44, no. 1, pp. 43-50, 1977.

[27] O. A. Yunev, V. I. Vedernikov, O. Basturk, et al., "Long-term variations of surface chlorophyll $a$ and primary production in the open Black Sea," Marine Ecology Progress Series, vol. 230, pp. 11-28, 2002.

[28] Z. M. Kuliyev, "Dynamics of Mnemiopsis distribution in the Azerbaijan sector of the Caspian Sea in 2001-2002," in Aquatic Invasions in the Black, Caspian and Mediterranean Seas: The Ctenophores Mnemiopsis leidyi and Beroe in the Ponto-Caspian and other Aquatic Invasions, H. Dumont, T. A. Shiganova, and U. Niermann, Eds., vol. 35, pp. 203-204, Kluwer Academic, Dordrecht, The Netherlands, 2004.

[29] G. C. Hays, A. J. Richardson, and C. Robinson, "Climate change and marine plankton," Trends in Ecology and Evolution, vol. 20, no. 6, pp. 337-344, 2005.

[30] J. D. R. Houghton, T. K. Doyle, M. W. Wilson, J. Davenport, and G. C. Hays, "Jellyfish aggregations and leatherback turtle foraging patterns in a temperate coastal environment," Ecology, vol. 87, no. 8, pp. 1967-1972, 2006.

[31] C. P. Lynam, M. R. Heath, S. J. Hay, and A. S. Brierley, "Evidence for impacts by jellyfish on North Sea herring recruitment," Marine Ecology Progress Series, vol. 298, pp. 157-167, 2005.

[32] K. A. Pitt, M. J. Kingsford, D. Rissik, and K. Koop, "Jellyfish modify the response of planktonic assemblages to nutrient pulses," Marine Ecology Progress Series, vol. 351, pp. 1-13, 2007. 

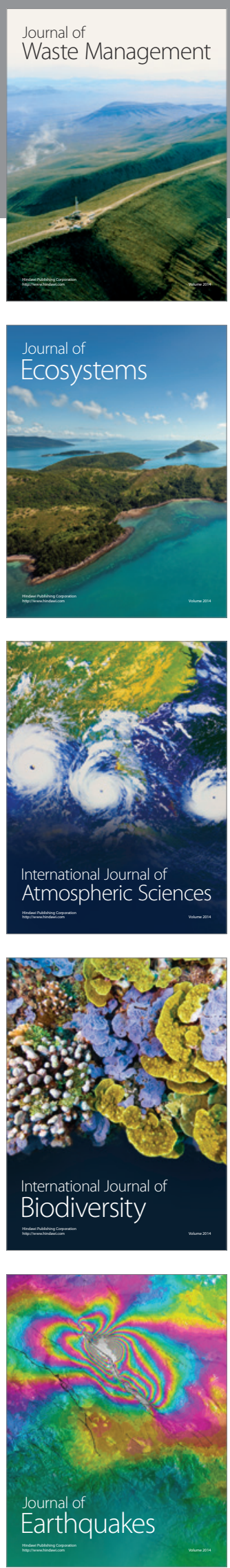
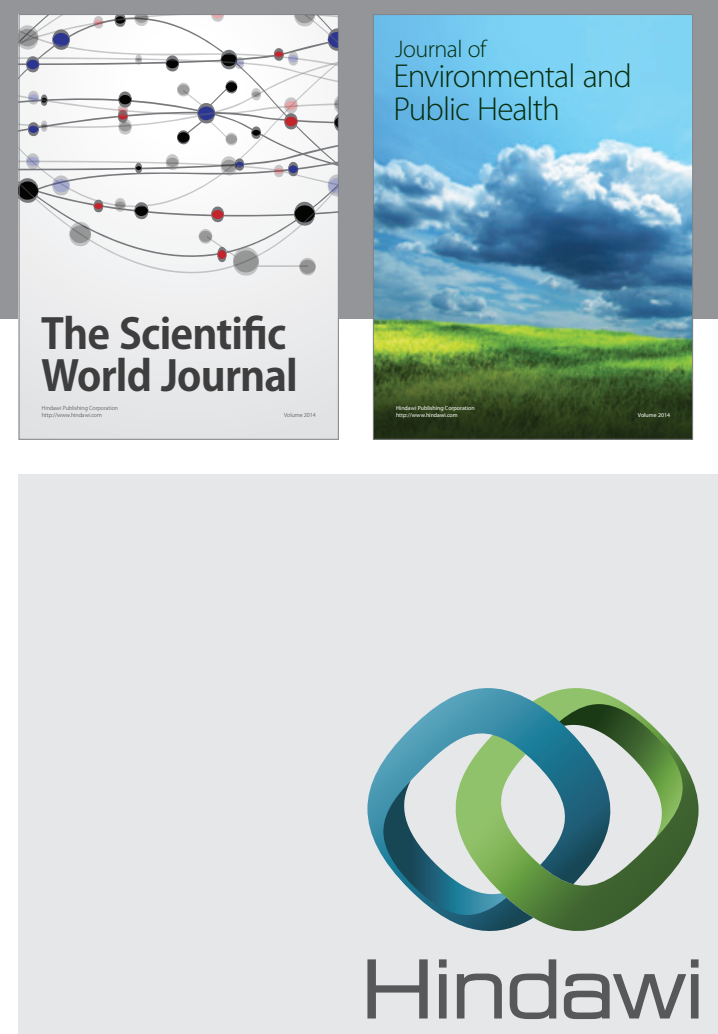

Submit your manuscripts at

http://www.hindawi.com
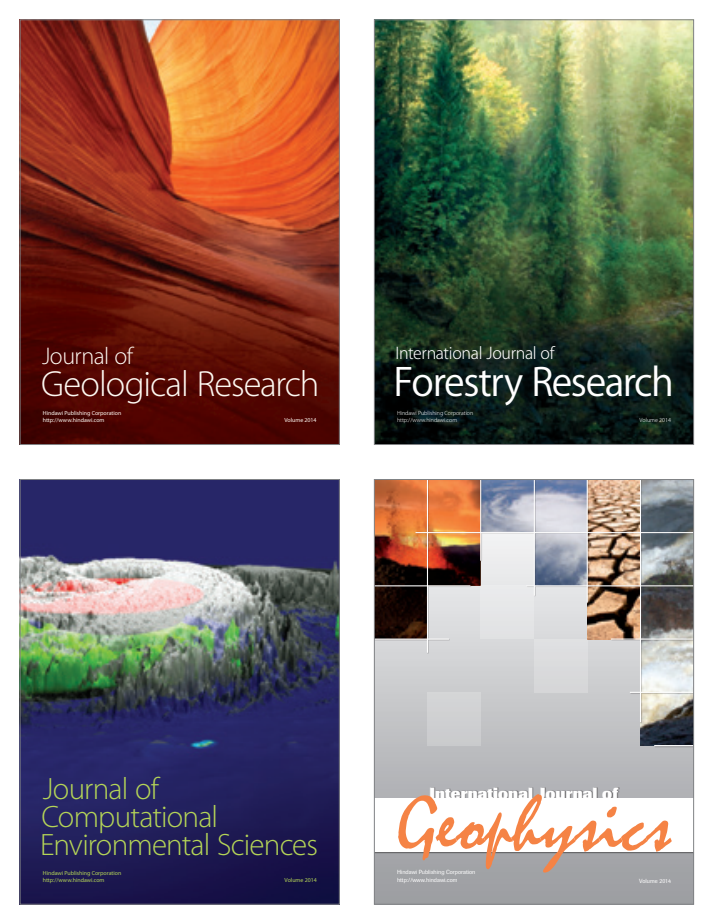
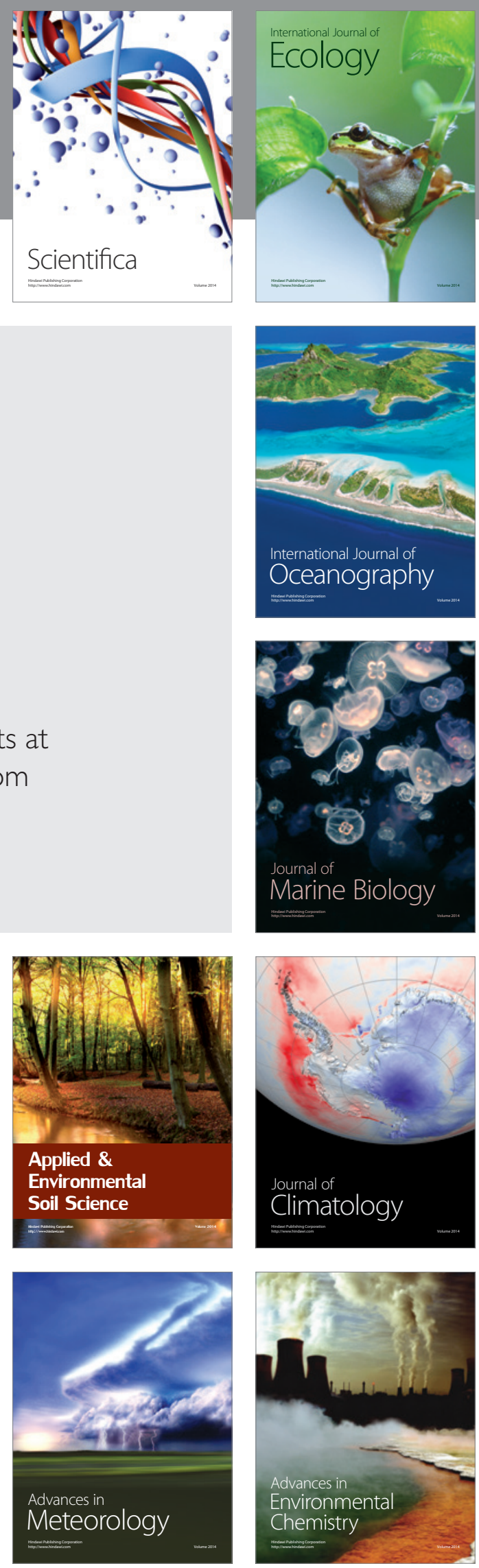